\title{
The Association between Toilet Training, Physical and Family History with Incident of Enuresis in Children at North Denpasar
}

\author{
A Lestarini ${ }^{1 *}$ and P S Prameswari ${ }^{1}$ \\ ${ }^{1}$ Faculty of Medicine and Health Sciences, Warmadewa University, Indonesia \\ *asrilestarini@gmail.com
}

\begin{abstract}
Enuresis, also known as bed-wetting is a condition where the children at the age of 5 or more urinate on the bed or on their clothes, and it happened often about at least twice a week for 3 months in a row. This research is dedicated to studying the relation between toilet training, physical and family history with the incident of enuresis in children between 5 and 6 years old. A cross-sectional study was conducted in North Denpasar District. The samples were 105 subjects whose study at kindergarten and their parent. Data of the risk factor of enuresis were collected by using questioner and then analysed by chi-square and Fisher exact test. The result of this research are children who had parents with enuresis history $(\mathrm{PR}=3,720)$, children who had siblings with enuresis history $(\mathrm{PR}=4,950)$, breastfeeding history $(\mathrm{PR}=1,920)$, duration of breastfeeding $(\mathrm{PR}=$ $2,133)$, toilet training $(\mathrm{PR}=5,497)$, and bad physiological history $(\mathrm{PR}=1,915)$ were related to incident of enuresis in children with p-value $<0,05$. Based on the result, parents, educators, or medical personnel may prevent the incident of enuresis by avoiding the risk factor of enuresis
\end{abstract}

Keyword : Association, Toilet Training, Pjysical and Family.

\section{Introduction}

Enuresis, also known as bedwetting, is urinating or voiding in bed or clothing in children aged five years or more, where at that age children should be able to urinate normally. According to the Diagnostic and Statistical Manual of Mental Disorders Fourth Edition (DSM-IV), children are said to experience enuresis if urinating or urinating as previously experienced with a frequency of at least twice a week for three consecutive months [1].

The highest incidence of children with enuresis is between the ages of 5 and 6 years. Survey results in Europe and North America show that 15-20\% of children aged 5 years, $7 \%$ of children aged 10 years, and 1-2\% of children aged 15 years' experience enuresis [2]. In the study in Malalayang District, Manado City, from 977 children, 78 people $(7.98 \%)$ had enuresis, and the highest prevalence was found in the 5-6 year age group, which was $18.92 \%$ $[3]$.

Most factors that often associated with enuresis include family history of enuresis, inadequate toilet training, a history of breastfeeding, and a child's psychological state [1]. The results showed that $77 \%$ of children with enuresis had a family history of both parents experiencing enuresis, while $44 \%$ of children with enuresis were found in families with a history of enuresis only in one of their parents [2]. In 2008 in Denpasar it was found that $48.5 \%$ of children with enuresis were not taught toilet training at the right age is. 2-3 years of age and urinary urgency occurred in $61 \%$ of children who experienced enuresis [4]. In New 
Jersey, found that $54.5 \%$ of children with enuresis only received breast milk for less than 3 months or not at all [5]. Child psychological factors such as stress are also associated with the incidence of enuresis, as in the study in Semarang, $31.9 \%$ of children with enuresis had a history of mild or severe stress [6]. The most common occurrence of enuresis in Denpasar was in the District of North Denpasar [4]. Based on the background described above, we need to know several factors that can cause enuresis in children so that prevention of enuresis can be done, especially in North Denpasar.

\section{Method}

The study design was a cross-sectional analytical design of 105 samples with systematic random sampling. The inclusion criteria of this study were all children aged 5-6 years who attended school in North Denpasar Sub district whose parents were willing to be respondents and did not have a history of abnormalities in their urinary system. Ethical feasibility was given by the Ethics Feasibility Institute of Udayana University/Sanglah Hospital in Denpasar. The data collected was primary data which was done by distributing and filling in the questionnaire. The questionnaire contained questions relating to the parent's history of enuresis, the history of siblings experienced enuresis, toilet training in children, a history of breastfeeding and the psychological condition of the child. Data analyzed by cross-tabulation and chi-square test or alternatives to determine the characteristics of the sample, the relationship between two variables, which were the relationship between the risk factors and enuresis, and to find out how much risk factors for enuresis can increase the incidence of enuresis in children. The $\mathrm{p}$ value $<0.05$ was said to be significant.

\section{Results And Discussion}

Data on the characteristics of the research subjects can be seen in table 1 below.

Table 1. Characteristics data of the research subjects

\begin{tabular}{cc}
\hline \multicolumn{1}{c}{ Characteristics } & n (\%) \\
\hline Age (year) & \\
5 & $45(42,9)$ \\
6 & $60(57,1)$ \\
Gender & \\
Male & $55(52,4)$ \\
Female & $50(47,6)$ \\
Total & $105(100)$ \\
\hline
\end{tabular}

In Table 1 it can be seen that the age of the subjects was evenly distributed between 5 and 6 years, and the number of men and women was balanced. After bivariate analysis, it was found that there was a significant relationship between the history of parents experiencing enuresis and the incidence of enuresis in children. From the test results obtained PR value of 3.720 (2.661-5.201) which means that children who have parents with a history of enuresis have a risk of having enuresis 3.7 times greater than children whose parents do not have a history of enuresis. From table 2 it is also found that children who have siblings with a history 
of enuresis will be at risk of experiencing enuresis 4.9 times greater than children whose siblings do not have a history of enuresis. Toilet training has the greatest influence by increasing the risk of enuresis 5.4 times greater if the quality of toilet training was not good enough.

The administration of breast milk and the duration of breastfeeding also significantly influence the incidence of enuresis in children. The analysis result from this data showed that children who did not get breast milk intake from birth will be at risk of experiencing enuresis 1.9 times higher than children who get breast milk. The PR value in table 2 was 2.1 which means that children who were breastfed for 6 months, less than 6 months, or who were not breastfed at all will be at risk of experiencing enuresis as much as 2.1 times greater than children who get ASI for more than 6 months. The same thing also happened when the child's personal psychology was disturbed. Children who had a disturbed psychological history will be at risk of experiencing enuresis 1.9 times greater than children who did not have a disturbed psychological history.

Table 2. Relationship between history of enuresis in parents, siblings, good quality toilet training, breastfeeding history and a child's psychological history towards the incidence of enuresis.

\begin{tabular}{|c|c|c|c|c|}
\hline Characteristic & Enuresis (37) & Non-Enuresis (68) & $\mathrm{N}=105 \mathrm{p}$ & PR $(\mathrm{CI})$ \\
\hline $\begin{array}{l}\text { History of } \\
\text { parents with } \\
\text { enuresis (n, \%) }\end{array}$ & & & & $3,720(2,661-5,201)$ \\
\hline Yes & $12(100 \%)$ & $0(0 \%)$ & $0,000 *$ & \\
\hline No & $25(26,9 \%)$ & $68(73,1 \%)$ & & \\
\hline $\begin{array}{l}\text { History of } \\
\text { siblings with } \\
\text { enuresis }(\mathrm{n}, \%)\end{array}$ & & & & $4,950(3,086-7,940)$ \\
\hline Yes & $22(91.7)$ & $68(64.8)$ & Yes & \\
\hline No & $15(18.5)$ & $66(81.5)$ & No & \\
\hline $\begin{array}{l}\text { Good quality } \\
\text { toilet training } \\
(\mathrm{n}, \%)\end{array}$ & & & & $5,497(2,658-11,370)$ \\
\hline Yes & 7 (11.9) & $52(88.1)$ & 0.000 & \\
\hline No & $30(65.2)$ & $16(34.8)$ & & \\
\hline Breastfed $(\mathrm{n}, \%)$ & & & & $1,920(1,1703,150)$ \\
\hline Yes & $25(29.8)$ & $59(70.2)$ & 0.036 & \\
\hline No & $12(57.1)$ & $9(42.9)$ & & \\
\hline $\begin{array}{l}\text { Duration of } \\
\text { breastfed }(\mathrm{n}, \%)\end{array}$ & & & & $2,133(1,217-3,579)$ \\
\hline$\leq 6$ month & $21(52.5)$ & $19(47.5)$ & 0.007 & \\
\hline$>6$ month & $16(24.6)$ & $49(75.4)$ & & \\
\hline $\begin{array}{l}\text { Disturbed } \\
\text { psychological } \\
\text { history of } \\
\text { children }(\mathrm{n}, \%)\end{array}$ & & & & $1,915(1,010-3,629)$ \\
\hline Yes & $28(43.1)$ & $37(56.9)$ & 0.043 & \\
\hline No & $9(22.5)$ & $31(77.5)$ & & \\
\hline
\end{tabular}

Parental history is associated with genetic factors. The genetic factor that associated in this case is the delay in maturation of central nervous system function. The gene involved in enuresis is a gene on chromosome 13q. In the next study it was found that there was a linkage 
of chromosome $12 \mathrm{q}$ and chromosome 22 . Children with parents with history of enuresis will be at greater risk of experiencing enuresis than children with parents who do not have a history of enuresis. As in previous studies it has been explained that if both parents have a history of enuresis, there was $77 \%$ chances of enuresis in their children. If only one of the two parents had a history of enuresis, their children will have $44 \%$ chances for enuresis [2], [7], [8]. The results in this study are in accordance with the theoretical review and research conducted by researcher [2] and [7] which states that history of enuresis in parents influence the increased incidence of enuresis in children.

History of siblings experiencing enuresis is associated with genetic factors similar to the history of parents who have enuresis. In monozygotic twins the enuresis rate is $43-68 \%$, whereas in dizygotic twins the enuresis rate is $19-36 \%$. In children who have siblings with a history of enuresis, then there will be $22 \%$ likelihood to have enuresis [2], [8], [9]. In this study, it was found that the history of siblings experiencing enuresis will increase the risk of enuresis. The results of this study are in accordance with the theoretical review and research conducted by researcher [2] and [9] which state that the history of sibling's enuresis affects the incidence of enuresis in children.

Toilet training is an attempt to train children to be able to control urination and defecation and do it in the right place [10]. Toilet training should be carried out when the child is 2 or 3 years old because at this age the spinal and sphincter reflex coordination is maturing. The implementation of toilet training is very important during children's development because it will shape the personality and discipline of children [2], [11], [12]. In this study, from a group of children who did not get a good quality of toilet training, $65.2 \%$ of children had enuresis. This shows that this study is in accordance with the theory review and previous research which states that there is a relationship between toilet training and the incidence of enuresis.

Giving breast milk to children can increase the development and maturity of the nervous system so that it can reduce the occurrence of enuresis. This has been clinically proven from several studies that compared breast-fed children with formula-fed children in the event of enuresis. In the study, it was found that there was a significant relationship between these variables. In a previous study it was found that as many as $45 \%$ of children with enuresis did not receive breast milk intake at birth [4] and there was a significant association between breastfeeding history factors for the incidence of enuresis [5]. These result was not much different from the results in this study, which showed that as many as $57.1 \%$ of children from the group of children who did not get breast milk had enuresis and found a significant relationship between breastfeeding history for the incidence of enuresis.

History of trauma, depression, or stress associated with the incidence of enuresis. Separation from family, death of parents, birth of siblings, new environment, fights of parents, or child abuse is a condition that is most often considered as a contributing factor to enuresis [2], [6], [13]. In a study in Semarang about the relationship between stress and enuresis, it was found that $61.7 \%$ of children who had experienced psychological disorders experienced enuresis [6], [14]. The results of the analysis of the two variables indicate that there was a significant relationship between the poor child's psychological factors for the incidence of enuresis. Based on the research data and the theoretical review that has been presented, it can be concluded that this research is in accordance with the theoretical review and previous research which states that the disturbed psychological history in children can increase the risk of enuresis. 


\section{Conclusions}

The conclusion of this study are the risk factors that have a significant influence on the incidence of enuresis consist of a history of parents with enuresis, siblings enuresis, good quality toilet training, breastfeeding and disturbed psychological history in children.

\section{References}

[1] Hooman N, Safaii A, Valavi E and Amini-Alavijeh Z 2013 Toilet Training in Iranian Children: a cross-sectional study. Iran J Pediatr. 23 154-8

[2] Alatas H, Tambunan T, Trihono T and Padede S 2002 Textbook on Children's Nephrology. Jakarta: Indonesian Faculty of Medicine Publisher Hall

[3] Umboh A, Wibisono JS 2002 Enuresis nokturnal pada anak sekolah dasar di Kecamatan Malalayang, Manado Maj. Kedokt.Indon. 52 97-101

[4] Windiani T and Soetjiningsih 2008 Prevalensi dan Faktor Risiko Enuesis pada Anak Taman Kanak-Kanak di Kotamadya Denpasar Sari Pediatri 10 151-7

[5] Barone JG 2006 Breastfeeding during infancy may protect against bed-wetting during childhood Pediatrics 118 254-9

[6] Fatmawati L and Mariyam 2013 Hubungan Stres dengan Enuresis pada Anak Usia Prasekolah di RA Al Iman Desa Banaran Gunung Pati Semarang Jurnal Keperawatan Anak 1 24-9

[7] Robson WL, Leung A and Van Howe R 2005 Primary and Secondary Nocturnal Enuresis: Similarities in Presentation. Pediatrics 115 956-9

[8] Ozden C, Ozdal OL, Altinova S, Oguzulgen I, Urgancioglu G and Memis A 2007 Prevalence and Associated Factors of Enuresis in Turkish Children Int Braz J Urol. 33 216-22

[9] Caldwell PH, Edgar D, Hodson E and Craig JC 2005 Bedwetting and Toileting Problems in Children Med J Aust. 182 190-5

[10]Eveline and Djamaludin 2010 Panduan Pintar Merawat Bayi dan Balita. Jakarta : Wahyu Media

[11] Hashem M, Morteza A, Mohammad K and Ahmad-Ali N 2013 Prevalence of Nocturnal Enuresis in School Age Children: The Role of Personal and Parent Related Socio-Economic and Educational Factors Iran J Pediatr. 23 59-64

[12] Van Hoecke E1, De Fruyt F, De Clercq B, Hoebeke P and Vande Walle J 2006 Internalizing and Externalizing Problem Behavior in Children with Nocturnal and Diurnal Enuresis: A FiveFactor Model Perspective J Pediatr Psychol. 31 460-8

[13] Witari NPD, Cahyawati PN, Lestarini A IOP Conf. Ser.: Mater. Sci. Eng. 434012029

[14] Andriyani S, Ibrahim K and Wulandari S 2014 Analisis Faktor-Faktor yang berhubungan dengan Toilet Training pada Anak Prasekolah Jurnal Keperawatan Padjadjaran 2 146-53 